\title{
Characterization of quality recycled gypsum and plasterboard with maximized recycled content
}

\author{
A. Jiménez-Rivero $\bowtie$, J. García-Navarro \\ Universidad Politécnica de Madrid, Research Group Sustainability in Construction and Industry giSCI-UPM, ETSIAAB. \\ (Madrid, Spain) \\ $\triangle$ ana.jimenez@upm.es
}

\author{
Received 9 May 2016 \\ Accepted 13 December 2016 \\ Available on line 19 October 2017
}

\begin{abstract}
The quality of secondary materials is imperative to promote a circular economy. In order to improve the way in which the quality of recycled gypsum is assessed, European guidelines on recycled gypsum (RG) quality criteria have been outlined in the framework of the Life+ Gypsum to Gypsum (GtoG) project. Such GtoG guidelines, along with the European Standard on gypsum plasterboard EN 520, provided the basis for this study. During the GtoG project, gypsum recycling and plasterboard manufacturing processes were monitored by testing the gypsum feedstock and the plasterboard produced. The aim of this paper is to discuss the results obtained on relevant parameters that characterize gypsum as a secondary raw material, as well as the resulting product. The minimum requirements were fulfilled by $56 \%$ of the RG samples and $86 \%$ of the plasterboard with increased RG.
\end{abstract}

KEYWORDS: Gypsum; Characterization; Physical properties; Mechanical properties; Flexural strength

Citation/Citar como: Jiménez-Rivero, A.; García-Navarro, J. (2017) Characterization of quality recycled gypsum and plasterboard with maximized recycled content. Mater. Construcc. 67 [328], e137. http://dx.doi.org/10.3989/ mc.2017.06016

RESUMEN: Caracterización de yeso reciclado de calidad y placa de yeso laminado con contenido reciclado maximizado. La calidad de las materias primas secundarias es fundamental para promover una economía circular. En el marco del proyecto Life+ Gypsum to Gypsum (GtoG), y con el objeto de mejorar el análisis de la calidad del yeso reciclado, se han desarrollado orientaciones en cuanto a los criterios de calidad del material. Estas directrices voluntarias, junto a la norma europea EN 520, son la base del presente trabajo. Los procesos de reciclaje y fabricación se monitorizaron durante el proyecto GtoG, mediante el ensayo de materias primas y placas de yeso laminado. El objetivo del presente artículo es discutir las propiedades del yeso como materia prima secundaria, así como del producto obtenido. Un 56\% de las muestras de RG y un $86 \%$ de las placas con aumento de contenido de $\mathrm{RG}$ cumplieron los requisitos mínimos establecidos.

PALABRAS CLAVE: Yeso; Caracterización; Propiedades físicas; Propiedades mecánicas; Resistencia a la flexión

ORCID ID: A. Jiménez-Rivero: (http://orcid.org/0000-0003-4013-2334); J. García-Navarro: (http://orcid.org/ 0000-0002-5268-1587)

Copyright: (C) 2017 CSIC. This is an open-access article distributed under the terms of the Creative Commons Attribution License (CC BY) Spain 3.0.

\section{INTRODUCTION}

Gypsum products mainly consist of calcium sulphate dehydrate $\left(\mathrm{CaSO}_{4} \cdot 2 \mathrm{H}_{2} \mathrm{O}\right)$, from three distinct sources: nature (mines or quarries), industrial processes and urban mining. It is feasible to recycle gypsum sourced from urban mining (known as endof-life (EoL) gypsum or post-consumer gypsum waste). In order to be recyclable, gypsum-based systems typically require deconstruction and separate collection of gypsum waste, which are part of the ideal conditions to produce quality recycled gypsum 
(RG) (1). However, the use of post-consumer RG is still very low in the European Union. For example, the weight percentage of post-consumer RG in a reference plasterboard in the year 2013 in the European Union was estimated to be $1 \%$ (2). In such reference plasterboard, three types of gypsum are dominant. Natural gypsum (i.e. from mines or quarries, 63\%), synthetic gypsum (i.e. from industrial processes, byproduct mainly from flue gas desulfurization systems, 27\%) and pre-consumer RG (from industrial processes, waste generated during the manufacturing process, commonly known as pre-consumer waste or industrial waste, $4 \%$ ). The remaining $5 \%$ correspond to lining paper and additives. Worth noting is that, in the European Union, a market for post-consumer RG has only emerged in Benelux, Scandinavia, France, the Netherlands and the UK (3).

Landfilling becomes the common destination of EoL gypsum in countries where a market for post-consumer RG has not yet emerged. Gypsum landfilling typically contributes to primary resource depletion, hydrogen sulphide and methane emissions from landfills (2). Around 1.9 million tonnes of EoL plasterboard were estimated to be generated in 2013 in the European Union, of which only $12.7 \%$ were recovered (for closed-loop recycling and other uses such as re-use). Different measures currently aim to mitigate such emissions, such as gypsum landfilling in specific monocells (4) or the examination of alternative landfill cover soils (5). But recycling, apart from avoiding the above mentioned harmful effects, is a mechanism to achieve resource efficiency and contribute to sustainable development (6).

The resulting $\mathrm{RG}$ can be used to manufacture new gypsum products, as a set retarder in Portland cement $(7,8)$ and to improve and treat soil (9). Gypsum is also a source of calcium and nutrient sulphur in agriculture (background information on the use of recovered soil fines from construction and demolition waste can be found in the study conducted by Jang and Townsend (2001), in which the leaching of sulphate from these fines due to the presence of gypsum plasterboard is examined. The present study explores the use of RG by the gypsum industry, which implies that the material loop is closed and enables the future re-use or recycling of the same gypsum products.

In order to be usable, RG should comply with the quality criteria threshold agreed between the final costumer and the recycler. Little was published about the diverse $\mathrm{RG}$ quality criteria before the beginning of the European Life+ Gypsum to Gypsum project "From production to recycling: a circular economy for the European gypsum Industry with the demolition and recycling Industry" (11). Knowledge on such existing quality criteria (3) can guide new costumers of RG (i.e. manufacturers aiming to reincorporate $R G$ in their process) towards preparing the most suitable agreements according to the nature of the manufacturing process (e.g. use of natural of synthetic feedstock, equipment). Moreover, the GtoG project has produced a set of European voluntary guidelines on the RG quality criteria for the gypsum industry, as a result of three years of collaborative works between agents' part of the value chain (12). These are the first harmonised guidelines at EU level covering technical and toxicological parameters (hereinafter GtoG guidelines on RG quality criteria). These guidelines are first introduced in Table 1 and Table 2, being the basis of the results and discussion section of this paper. The works included pilot projects (deconstruction, recycling and manufacturing processes) in distinct European locations (France, the UK, Germany, Belgium and the Netherlands). Producers, recyclers and laboratory Loemco (Official Laboratory for Testing Materials of Construction, third party laboratory) discussed the test results and agreed on initial guidelines (12). The samples were collected by Loemco, between February 2014 and January 2015. Most of the tests were carried out by this laboratory, except those related to radioactivity and total organic carbon (TOC), which were conducted by Laboratory for Gamma-ray Spectrometry in Belgium (SCK- CEN) and Instituto Técnico de Materiales y Construccciones in Spain (Intemac), respectively. Moreover, nickel testing was also conducted by Institut Frenesius in Germany (SGS).

The present study focuses on test results from five European pilot projects, which included 21 gypsum feedstock samples and 13 plasterboard samples. The aim is to analyse relevant parameters that characterize gypsum as a raw material (business-as-usual (BAU) gypsum feedstock and RG feedstock) and gypsum products (BAU plasterboard and plasterboard with up to $30 \%$ reincorporation of $R G$ ). This paper discusses the quality of the gypsum feedstock against the GtoG guidelines on RG quality criteria (See Section 3.1) as well as the properties of the final products against the relevant standard (13), as detailed in Section 3.2.

\section{MATERIALS AND METHODS}

\subsection{Gypsum as feedstock: recycled gypsum (RG) quality criteria}

The experimental methods used for the assessment of the RG quality criteria parameters conformed with four European documents as follows. The Instruction Sheet VGB-M 701 (14) for the case of free moisture, purity, salts and $\mathrm{pH}$; the European Standard EN 933-1 (15) for the particle size results (maximum size measured in Table 1 and particles below $4 \mathrm{~mm}$ in Figure 1); EN 13137 (16) for assessing the TOC and EN ISO 11885 (17) for analysing the toxicological parameters. Additionally, the radioactivity index was calculated according to the 
TABLE 1. Technical parameters analysis

\begin{tabular}{|c|c|c|c|c|c|c|c|c|c|c|c|}
\hline \multirow[b]{2}{*}{ Parameter } & \multirow[b]{2}{*}{ Unit } & \multirow[b]{2}{*}{$\begin{array}{l}\text { Reference } \\
\text { standard }\end{array}$} & \multirow{2}{*}{$\begin{array}{c}\text { GtoG } \\
\text { guidelines on } \\
\text { RG quality } \\
\text { criteria }^{\text {a }}\end{array}$} & \multicolumn{4}{|c|}{$\begin{array}{c}\text { Business-as-usual (BAU) gypsum } \\
\text { feedstock }\end{array}$} & \multicolumn{4}{|c|}{ Recycled gypsum (RG) feedstock } \\
\hline & & & & M & SD & Min & Max & M & SD & Min & Max \\
\hline Maximum size & $\mathrm{mm}$ & EN 933-1 & 15.00 & 7.38 & 9.89 & 0.10 & 20.00 & 8.00 & 4.00 & 2.00 & 14.00 \\
\hline Free moisture & $\% \mathrm{w} / \mathrm{w}$ & VGB-M 701 & $<10$ & 3.02 & 3.01 & 0.05 & 6.85 & 6.91 & 5.05 & 0.27 & 17.14 \\
\hline Purity & $\% \mathrm{w} / \mathrm{w}$ & VGB-M 701 & $>80$ & 91.78 & 2.57 & 89.01 & 96.41 & 87.41 & 3.36 & 79.83 & 90.64 \\
\hline $\begin{array}{l}\text { Total organic } \\
\text { carbon (TOC) }\end{array}$ & $\% \mathrm{w} / \mathrm{w}$ & EN 13137 & $<1.5$ & 0.17 & 0.28 & 0.01 & 0.83 & 0.85 & 0.72 & 0.19 & 3.13 \\
\hline Magnesium salts & $\% \mathrm{w} / \mathrm{w}$ & VGB-M 701 & $<0.1$ & 0.01 & 0.00 & 0.00 & 0.01 & 0.02 & 0.01 & 0.01 & 0.04 \\
\hline Sodium salts & $\% \mathrm{w} / \mathrm{w}$ & VGB-M 701 & $<0.06$ & 0.01 & 0.01 & 0.00 & 0.02 & 0.02 & 0.01 & 0.02 & 0.07 \\
\hline Potassium salts & $\% \mathrm{w} / \mathrm{w}$ & VGB-M 701 & $<0.05$ & 0.00 & 0.00 & 0.00 & 0.01 & 0.02 & 0.01 & 0.01 & 0.04 \\
\hline Soluble chloride & $\% \mathrm{w} / \mathrm{w}$ & VGB-M 701 & $<0.02$ & 0.00 & 0.00 & 0.00 & 0.01 & 0.02 & 0.03 & 0.01 & 0.12 \\
\hline $\mathrm{pH}$ & - & VGB-M 701 & $6-9$ & 7.54 & 0.65 & 6.50 & 8.51 & 8.13 & 0.47 & 7.53 & 8.91 \\
\hline
\end{tabular}

${ }^{\mathrm{a}}$ In accordance with (12).

Total organic carbon (TOC), magnesium salts $(\mathrm{MgO})$, sodium salts $\left(\mathrm{Na}_{2} \mathrm{O}\right)$, potassium salts $\left(\mathrm{K}_{2} \mathrm{O}\right)$, soluble chloride $(\mathrm{Cl})$.

$\mathrm{M}$ : mean value; SD: standard deviation; Min: minimum; Max: maximum. Maximum size measured could not be assessed for the samples $\mathrm{G}(\mathrm{M})-2$ and $\mathrm{G}(\mathrm{M})-4$.

RP 112 document and the asbestos content was analysed according to the Rietveld method (18).

The limit values of the technical parameters (see column "GtoG guidelines on RG quality criteria" in Table 1) are based on previous criteria developed by the quality protocol in the UK (19) and BV Gips in Germany (20), being the later used as a benchmark. The guidelines for the toxicological parameters (see column "GtoG guidelines on RG quality criteria" in Table 2) are also based on the criteria developed by BV Gips in Germany (20), which in turn is based on the study conducted by Beckert on natural and flue gas desulfurization (FGD) gypsum (21).

The raw materials object of study (natural, FGD and $\mathrm{RG}$ ) were collected from the GtoG pilot projects $(\mathrm{N}=21)$. These included BAU and $\mathrm{RG}$ feedstock as detailed below.

- BAU gypsum feedstock for plasterboard manufacturing $(\mathrm{N}=8)$. Samples are labelled as $\mathrm{G}(\mathrm{F} / \mathrm{N} /$ R)-No. Three samples come from plants using FGD gypsum $(\mathrm{G}(\mathrm{F})-1, \mathrm{G}(\mathrm{F})-2$ and $\mathrm{G}(\mathrm{F})-3)$. Four samples come from plants using natural gypsum $(\mathrm{G}(\mathrm{N})-1, \mathrm{G}(\mathrm{N})-2, \mathrm{G}(\mathrm{N})-3$ and $\mathrm{G}(\mathrm{N})-4)$. One sample corresponded to pre-consumer $\mathrm{RG}$ (G(R)-1).

- $\quad$ RG feedstock for plasterboard manufacturing $(\mathrm{N}=13)$, including pre-consumer (from plasterboard production) and post-consumer RG samples (gypsum-based systems were dismantled from renovation works, segregated on-site and transported to the recycler. Samples were labelled as RG-No.

\subsection{Plasterboard: physical and mechanical properties}

Plasterboard samples were tested by Loemco during the GtoG pilot projects according to the European standard EN 520:2005+A1:2010 (13). In this study we examined the density $\left(\mathrm{kg} / \mathrm{m}^{3}\right)$, flexural strength (expressed as flexural breaking load) both transverse and longitudinal direction $(\mathrm{N})$, surface water absorption $\left(\mathrm{g} / \mathrm{m}^{3}\right)$ and surface hardness $(\mathrm{mm})$ results.

Plasterboard samples were type A, considered as the standard plasterboard (13), with nominal board thickness of $12.5 \mathrm{~mm}$. Further details on the samples are detailed below.

- BAU plasterboard $(\mathrm{N}=6)$. In these five plants, common reincorporation rates of $\mathrm{RG}$ ranges from $5 \%$ to $15 \%$ by weight. Samples are labelled as PB-No.

- Plasterboard with increased RG content $(\mathrm{N}=7)$. During the GtoG production trials the new composition included between 17 and $28 \%$ of $\mathrm{RG}$ content (i.e. the plasterboard sample with lower RG content achieved $17 \%$ by weight). Samples are labelled as PB-RG-No.

\section{RESULTS AND DISCUSSION}

\subsection{Gypsum as feedstock: business-as-usual (BAU) versus recycled gypsum (RG) feedstock}

Table 1 shows information on the average results obtained for the technical parameters. Additionally, 


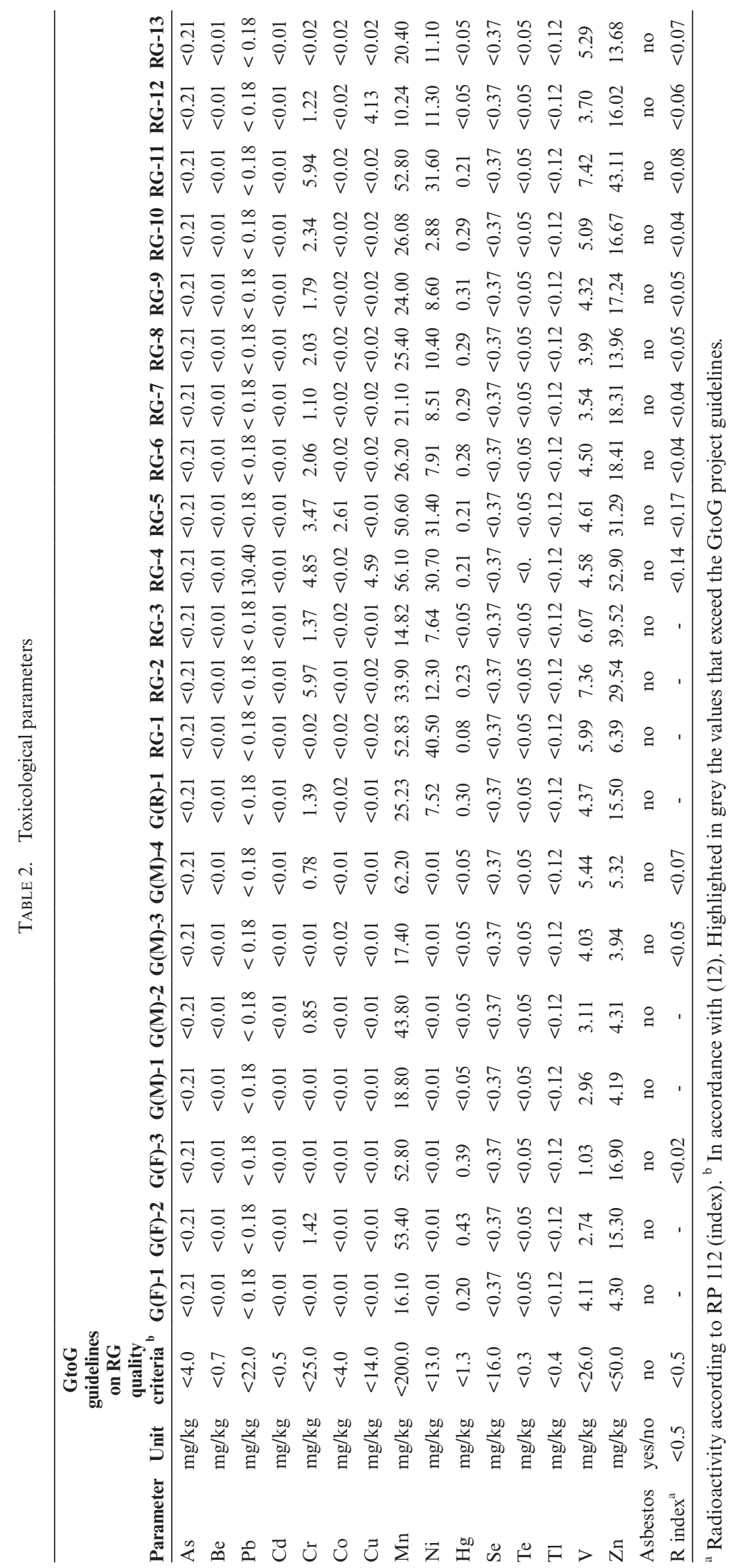


TABLE 3. Physical and mechanical characterization of plasterboard samples

\begin{tabular}{|c|c|c|c|c|c|c|c|c|c|c|}
\hline \multirow[b]{2}{*}{ Parameter } & \multirow[b]{2}{*}{ Unit } & \multirow[b]{2}{*}{ EN 520 ${ }^{\mathrm{a}}$} & \multicolumn{4}{|c|}{ Business-as-usual (BAU) plasterboard } & \multicolumn{4}{|c|}{$\begin{array}{l}\text { Plasterboard with increased recycled gypsum } \\
\text { (RG) content }\end{array}$} \\
\hline & & & M & SD & Min & Max & $\mathbf{M}$ & SD & Min & Max \\
\hline $\begin{array}{l}\text { Flexural } \\
\text { breaking load } \\
\text { (Longitudinal) }\end{array}$ & $\mathrm{N}$ & $\geq 550$ & 606.67 & 24.48 & 577.00 & 631.00 & 587.57 & 27.91 & 548.00 & 619.00 \\
\hline $\begin{array}{l}\text { Flexural } \\
\text { breaking load } \\
\text { (Transversal) }\end{array}$ & $\mathrm{N}$ & $\geq 210$ & 229.83 & 10.91 & 215.00 & 245.00 & 249.14 & 48.20 & 217.00 & 353.00 \\
\hline $\begin{array}{l}\text { Surface water } \\
\text { absorption } \\
\text { (Face) }\end{array}$ & $\mathrm{g} / \mathrm{m}^{2}$ & $\leq 300^{\mathrm{b}}$ & 181.83 & 18.51 & 160.00 & 212.00 & 193.43 & 31.64 & 166.00 & 262.00 \\
\hline $\begin{array}{l}\text { Surface water } \\
\text { absorption } \\
\text { (Back) }\end{array}$ & $\mathrm{g} / \mathrm{m}^{2}$ & - & 287.83 & 174.45 & 157.00 & 585.00 & 205.14 & 37.46 & 179.00 & 276.00 \\
\hline Density & $\mathrm{kg} / \mathrm{m}^{3}$ & $\geq 600$ & 701.67 & 30.55 & 644.00 & 732.00 & 693.43 & 24.39 & 663.00 & 724.00 \\
\hline $\begin{array}{l}\text { Surface } \\
\text { hardness }\end{array}$ & $\mathrm{mm}$ & - & 16.50 & 2.81 & 11.00 & 19.00 & 12.71 & 3.35 & 10.00 & 18.00 \\
\hline
\end{tabular}

${ }^{\text {a }}$ Reference standard EN 520, requirement for type A, $12.5 \mathrm{~mm}$.

${ }^{\mathrm{b}}$ Different levels depending on the water absorption class (H1, H2, H3). H3 is here considered.

M: mean value; SD: standard deviation; Min: minimum; Max: maximum.

Further details on the properties of BAU plasterboard and plasterboard with increased RG content can be found in Section 2.2.

Figure 1 presents the values per sample. These parameters, along with the toxicological ones (detailed in Table 2) are part of the quality criteria for the use of RG into new gypsum products.

Only $56 \%$ of the RG samples complied with the GtoG guidelines on RG quality criteria. Two groups of non-compliant samples can be distinguished. The first group included RG-1, RG-8, RG-9 and RG-10, which presented technical parameters above the threshold (i.e. free moisture and TOC) that could have been corrected with a properly managed deconstruction-recycling value chain (See Section 3.1.1 to Section 3.1.5). The second group of samples included RG-4, RG-5 and RG-11, which presented toxicological parameters above the threshold of unknown origin (See Section 3.1.6).

\subsubsection{Particle size}

The GtoG guidelines on RG quality criteria concerning the parameter "Particle size" were fulfilled by all samples. In average, BAU gypsum feedstock and RG feedstock had similar maximum size. However, the deviation was higher for the case of BAU (7.38 $\pm 9.89)$ compared to the $\mathrm{RG}$ feedstock $(8.00 \pm 4.00)$. Moreover, the minimum size varied greatly between samples $(0.10 \mathrm{~mm}$ in the BAU samples, compared to $2.00 \mathrm{~mm}$ in the RG feedstock). This is mainly due to plant specifics. For example, plants operating with FGD feedstock $(\mathrm{G}(\mathrm{F})-1, \mathrm{G}(\mathrm{F})-2, \mathrm{G}(\mathrm{F})-3)$, showed a maximum particle size of $0.1 \mathrm{~mm}$, while plants using mined feedstock presented a maximum value of $20 \mathrm{~mm}$. The requirements on particle size will therefore vary according to the needs of each plant. In this line, plants that use natural gypsum typically accept higher particle sizes while FGD plants have more strict requirements (18). It should be noted that the particle size was analysed in terms of the maximum size measured (see Table 1) and the particles below $4 \mathrm{~mm}$ (see Figure 1). The particles below $4 \mathrm{~mm}$ were measured in order to better understand the particle distribution of the RG, being such maximum particle size formerly provided by a EU recycler. Finally, the GtoG guidelines only established threshold values for the maximum size.

Variations in the particle size distribution of feedstock may affect the calcination rate (i.e. higher times for coarser compared to finer particle sizes) and thereby the calcination efficiency. Thus, the particle size of RG should be in line with the conventional feedstock used by the manufacturer.

\subsubsection{Free moisture}

This parameter was above the threshold (10 $\% \mathrm{w} / \mathrm{w})$ in $23 \%$ of the RG samples object of study (RG-8, RG-9, RG-10, see Figure 1), being the maximum value measured $17.14 \% \mathrm{w} / \mathrm{w}$. Therefore, special attention should be paid to free moisture in order to comply with the RG quality criteria. This moisture in post-consumer RG can be limited with the use of covered skips for EoL gypsum from deconstruction to recycling, the duration and conditions of storage. Free moisture can be also reduced by mixing wet RG loads with drier ones (22). The average free moisture obtained for the BAU gypsum feedstock 


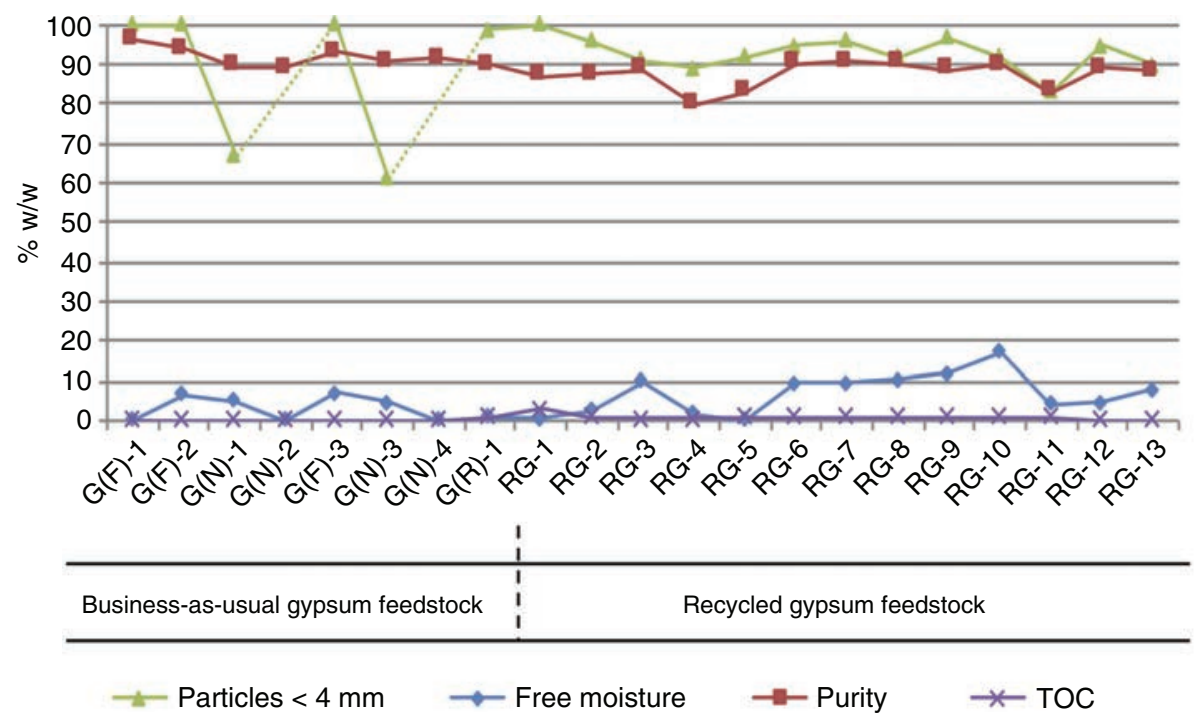

FIGURE 1. Detailed values per sample on the particle size results (in terms of rate of particles below $4 \mathrm{~mm}$ ), free moisture, purity and total organic carbon (TOC). Business-as-usual feedstock includes samples labelled as G(F/M/R)-No. N: natural gypsum. F: FGD gypsum. R: recycled gypsum. RG feedstock includes samples labelled as RG-No. Therefore, a sample labelled as G(F)-01 comes from business-as-usual feedstock, and it is mainly composed of FGD gypsum. Particles below 4 mm could not be measured for the samples $\mathrm{G}(\mathrm{N})-2$ and $\mathrm{G}(\mathrm{N})-04$.

$(3.02 \pm 3.01)$ compares well with data from Venta (1997), in which values between 1 and 3\% free moisture content in natural gypsum are reported. The higher standard deviation is mainly due to BAU samples from plants using mainly FGD as gypsum feedstock (e.g. G(F)-2 and G(F)-3, 6.64\%w/w and $6.85 \% \mathrm{w} / \mathrm{w}$ free moisture content, respectively).

Reincorporation of $\mathrm{RG}$ with high free moisture content may pose a technical problem since the material would need additional drying operations. Such extra processes would require higher primary energy and costs. As a consequence, the Eurogypsum Recycling Working Group recommends to limit free moisture of RG to $5 \%(12,18)$.

\subsubsection{Purity}

This parameter refers to the content of calcium sulphate dehydrate $\left(\mathrm{CaSO}_{4} \cdot 2 \mathrm{H}_{2} \mathrm{O}\right)$ in the material. One sample (RG-4) did not comply $(79.83 \%$ w/w purity) with the agreed GtoG guidelines (see Figure 1). Such value could be suitable for cement production, which commonly require lower purities, probably because of the content variation in the process (24). As with the particle size, the purity of gypsum products varies between manufacturing plants. This is especially evident between gypsum products manufactured in plants using FGD gypsum (i.e. high purity, above $95 \%$ according to (25)) compared to plants using natural gypsum (i.e. purity commonly ranges from $80 \%$ to $96 \%$ according to Henkels \& Gaynor (1996); values in line with $91.28 \%$ purity measured by Chandara et al. (2009)). This variability will hence affect the purity of the
EoL gypsum from the building stock. In this study, purity of the BAU gypsum feedstock was around $4 \%$ w/w higher compared to RG feedstock. GtoG guidelines on RG quality criteria establish minimum $80 \%$ purity, and the Eurogypsum Recycling Working Group recommends a value of at least $85 \%$ (12). In any case, these guidelines should be adapted to each particular context. For example, the Italian gypsum association demands purity higher than $75 \%$ by weight (3). By contrast, the UK document PAS 109 (27) and BV Gips require values above 85\% w/w (20).

Purity affects the primary energy use of the calcination stage during the manufacturing process, due to the content of chemically bound water (i.e. higher purity requires higher energy demand) (18). On the other hand, the higher the purity, the lower the weight of the gypsum product and the effects of potential impurities, which makes hither purity a desired parameter (26).

\subsubsection{Total organic carbon (TOC)}

The value of TOC varies with the content of residual paper in the RG. This paper waste comes from the lining paper in plasterboard. Although the existing technology for processing EoL gypsum is designed to separate the paper from the gypsum core, traces of paper waste may remain in the recycled material. Such traces should be limited in order to warrant confidence on RG. In this study, one sample exceeded the TOC threshold in the GtoG guidelines on RG quality criteria (RG1, TOC $=3.13$ ), which was attributed to the nature 
of this sample (RG-1 corresponded to only preconsumer RG). Such high TOC values are likely to be found in pre-consumer RG. Such RG is often recycled by the manufacturer, by using equipment that may not separate the lining paper from the gypsum core (22).

High TOC values affect the fluidity of the slurry and increases the excess of water demand. The residual paper should therefore be kept at the minimum possible level. The Eurogypsum Recycling Working Group recommends TOC below 1.0\% w/w (12).

\subsubsection{Water soluble salts and $p H$}

Water soluble salts include magnesium, sodium, potassium and chloride. These salts can be found in all types of gypsum, and therefore they are not particularly linked to the use of RG. However, a high content of salts can be due to high amounts of residual paper (18). The only sample that presented a high TOC content (RG-1), also showed a high sodium $(0.066 \% \mathrm{w} / \mathrm{w})$ and chloride $(0.124 \% \mathrm{w} / \mathrm{w})$ content. On the other hand, the $\mathrm{pH}$ value complied in all cases.

The presence of soluble salts affects the paper bonding in plasterboard production. This is due to the migration of salts to the interface between the paper and the gypsum core, during the drying of plasterboard in drying kilns. These potential deposits of salts could cause the detachment of paper from the gypsum core during installation, particularly when plasterboard is exposed to high moisture (26).

\subsubsection{Toxicological parameters}

Toxicological parameters are related to potential heavy metal trace elements in the gypsum feedstock. Table 2 shows the relevant parameters part of the GtoG guidelines on RG quality criteria. It is worthwhile mentioning that these threshold values are considered by the gypsum industry as a starting point, to be redefined for the case of RG (12). In this study, $100 \%$ of the BAU gypsum feedstock and $69 \%$ of the RG samples complied with the GtoG guidelines. One sample (RG-4) had a high content of lead, nickel and zinc (see Table 2), of unknown origin. Three samples (RG-1, RG-5 and RG-11) exceeded the nickel content. In order to further investigate these results, Institut Frenesius (SGS) conducted a second analysis on eight samples of feedstock, which resulted on values of nickel below the threshold (in samples which nickel content varied between $<0.01$ and $>10.00$ in the GtoG analysis). Discrepancy between the results suggests that further investigation is needed on the procedures and testing methods for trace elements (18).

\subsection{Plasterboard: business-as-usual (BAU) versus plasterboard with increased recycled gypsum (RG) content}

Table 3 shows information on the average results obtained for the physical and mechanical characterization of plasterboard samples. All samples except PB-RG-3 complied with the EN 520 requirements for type A plasterboard, $12.5 \mathrm{~mm}$ nominal board thickness, water absorption class H3. PB-RG-3 presented a flexural breaking load longitudinal $(548 \mathrm{~N})$ slightly below the EN 520 requirement $(550 \mathrm{~N})$.

\subsubsection{Mechanical characterization}

In six of the seven samples of plasterboard with increased RG content (86\%) flexural breaking load (both transversal and longitudinal) was above the EN 520 requirements (Longitudinal: 550 N, Transversal: 210 N, see Figure 2), being the flexural breaking load longitudinal of PB-RG-9 slightly below the relevant requirement $(548 \mathrm{~N})$. Overall, the flexural breaking load of plasterboard with increased RG content was 3\% reduced (longitudinal) and 8\% increased (transversal) compared to BAU plasterboard reference values (Table 3). Nevertheless, it could not be proved that the reduction of flexural breaking load longitudinal was caused by the higher amount of RG. Moreover, it is considered feasible to increase the strength with minor changes in the process (18).

\subsubsection{Physical characterization}

Three physical properties were analysed as described in Section 2.2: density, surface water absorption and surface hardness. In any case, the results were well above the EN 520 requirement. In average, the density of plasterboard with increased RG content was about $1 \%$ lower than BAU plasterboard density. On the contrary, the minimum density value for plasterboard with increased RG content $\left(663.00 \mathrm{~kg} / \mathrm{m}^{3}\right.$, which corresponded to PB-RG-8, see Table 3) resulted $3 \%$ higher than the minimum BAU plasterboard value $\left(644 \mathrm{~kg} / \mathrm{m}^{3}\right.$, which corresponded to PB-3, see Table 3). This variability was mainly attributed to adjustments of the line speed during the manufacturing trials (18).

Regarding surface water absorption (face), all samples complied with EN 520 requirements, and were around $0.6 \%$ higher for the case of plasterboard with increased RG (see Table 3). A stricter water absorption class (H2) requires surface water absorption values below $220 \mathrm{~g} / \mathrm{cm}^{2}$, which is also fulfilled by $86 \%$ of the plasterboard samples with increased RG (Figure 3). On the other hand, the average surface water absorption (back) decreased from $287.83 \mathrm{~g} / \mathrm{m}^{2}$ (BAU plasterboard) to $205.14 \mathrm{~g} / \mathrm{m}^{2}$ (plasterboard with increased RG content). These differences were attributed to the different formula and batch tested (18). 

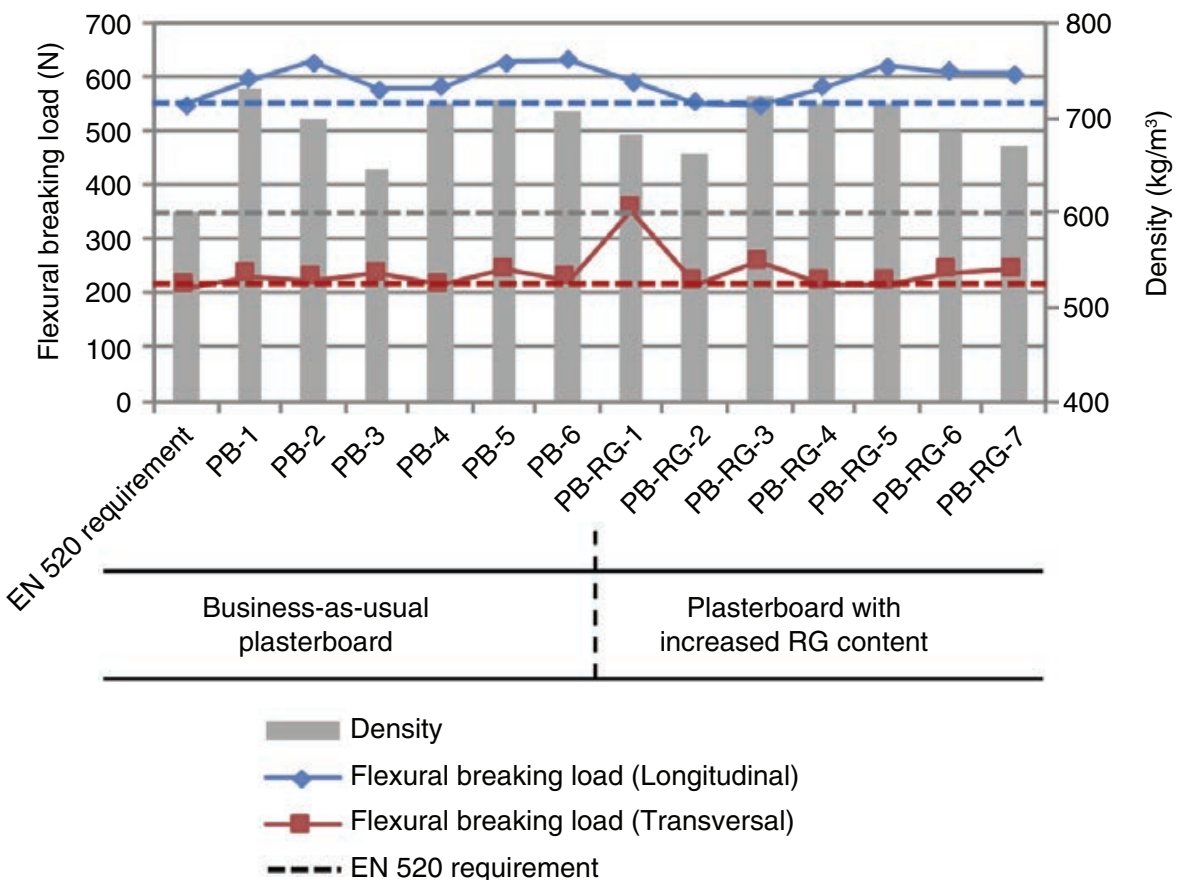

FIGURE 2. Detailed values per sample on the flexural breaking load and density. Samples labelled as PB -No are part of BAU plasterboard. Plasterboard with increased RG content includes samples labelled as PB-RG-No. The figure also draws the minimum requirement established by the European Standard EN 520 (CEN, 2009), for gypsum plasterboard type A, $12.5 \mathrm{~mm}$.

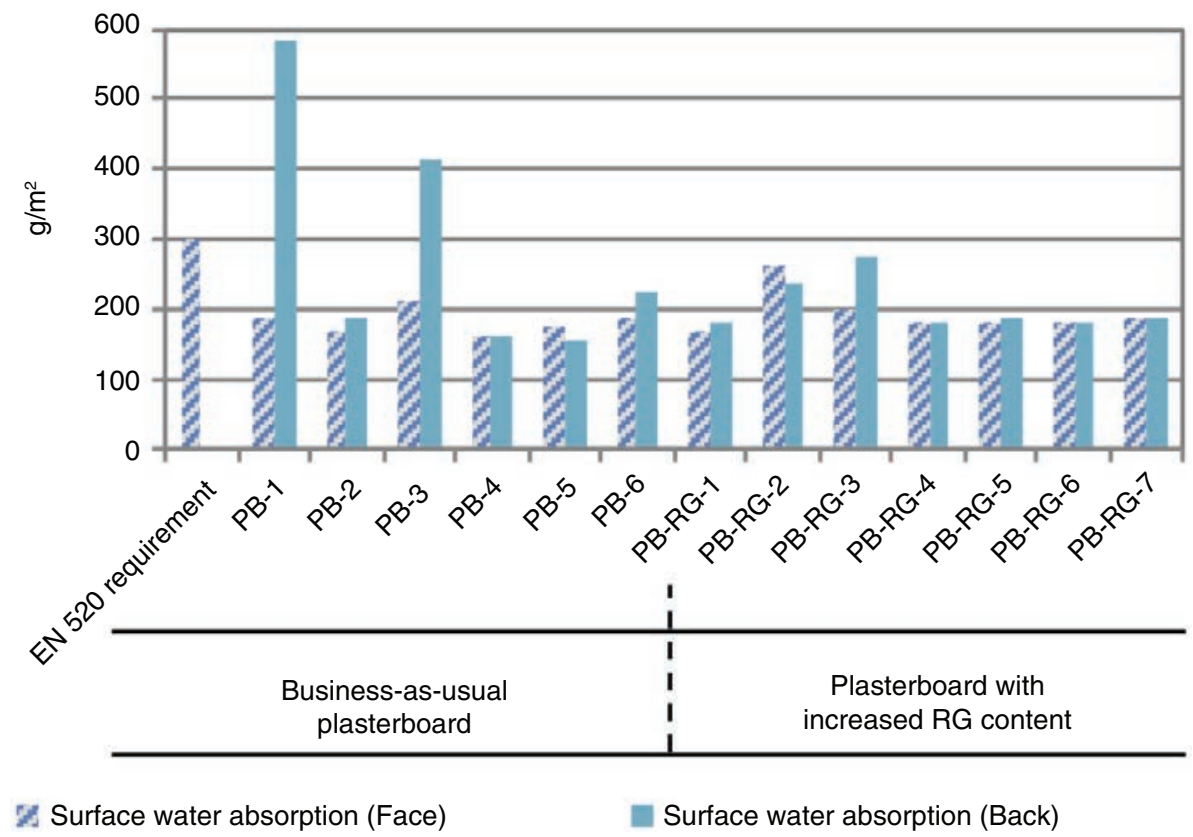

FIgURE 3. Water absorption per sample. Samples labelled as PB -No are part of BAU plasterboard. Plasterboard with increased RG content includes samples labelled as PB-RG-No. The figure also draws the minimum requirement established by the European Standard EN 520 (CEN, 2009), for gypsum plasterboard type A, $12.5 \mathrm{~mm}$.

With respect to surface hardness, it is characterised by the diameter of the depression produced in the surface of the plasterboard. Note that higher measured diameter means fewer impact resistance of the board. There is no minimum EN 520 requirement for type A plasterboard. However, there is an additional requirement for gypsum plasterboard type I (with enhanced surface hardness). This 
requirement entails diameters not greater than 15 $\mathrm{mm}$, which was fulfilled by $70 \%$ of the plasterboard with increased RG content samples (in comparison with $14 \%$ of BAU plasterboard). When comparing BAU plasterboard and plasterboard with increased RG (PB-RG) samples, the values from PB-RG were around $30 \%$ higher than those from BAU plasterboard.

\section{CONCLUSIONS}

The present work has analysed data from testing gypsum feedstock (business-as-usual, BAU and recycled gypsum, RG) as well as gypsum plasterboard (type A, $12.5 \mathrm{~mm}$ ) with up to $30 \%$ of $\mathrm{RG}$ content. The results have been discussed according to the existing voluntary guidelines on RG quality criteria for the gypsum industry (for the case of gypsum feedstock) and the European standard EN-520 (for the case of gypsum plasterboard).

With respect to gypsum feedstock, the GtoG guidelines on RG quality criteria were fulfilled by only $56 \%$ of the RG samples. However, most of these parameters can be typically managed by the deconstruction-recycling value chain (e.g. free moisture, total organic carbon (TOC)), by applying effective deconstruction processes (i.e. dismantling, separate collection), and adequate recycling procedures and equipment (i.e. sorting operations prior to waste processing, equipment with high output of paper waste). In any case, technical parameters should be adapted to the specifics of each plant and technical and toxicological values should be periodically monitored. The assessment of the RG samples against the GtoG voluntary guidelines is summarized below:

- The "Particle size" requirements (i.e. particles below $15 \mathrm{~mm}$ ) were met by all samples.

- $\quad 77 \%$ of the samples complied the "Free moisture" voluntary threshold (i.e. 10\%), due to three non-compliant samples (i.e. RG-8, RG-9 and RG-10).

- $\quad 92 \%$ of the samples met the minimum value for "Purity", as one of the thirteen samples (RG-4) did not comply with the minimum requirement (i.e. $80 \%$ ). However, the difference was minimal $(79.83 \%)$. Purity of RG feedstock was around $4 \% \mathrm{w} / \mathrm{w}$ lower compared to business-as-usual gypsum feedstock.

- The "Total organic carbon (TOC)" was exceeded by one sample (RG-1), explained by its nature (pre-consumer RG, which might not have undergone paper separation). This sample also presented "Water soluble salts" above the threshold, which appear to be linked to high TOC values.

- The "pH" requirement (i.e. between 6 and 9) was met by all samples.
- $69 \%$ of the samples fulfilled all "Toxicological parameters", as four samples (RG-1, RG-4, RG-5 and RG-11) did not comply with any of the established parameters (i.e. lead, nickel, zinc). Regarding the zinc content, discrepant test results suggest that procedures and testing methods for trace elements should be further investigated.

As regards the tested gypsum plasterboard with increased RG content (between 17 and $28 \%$ ), $86 \%$ of the samples has shown compliance with the mechanical and physical requirements for plasterboard type A, $12.5 \mathrm{~mm}$, in accordance to the European Standard EN-520. By comparing the results with the minimum requirements in this Standard, the following conclusions can be drawn:

- $86 \%$ of the samples met the EN 520 mechanical requirements for type A plasterboard, $12.5 \mathrm{~mm}$ nominal board thickness. Only one sample (PBRG-3) presented flexural breaking load longitudinal slightly below the relevant requirement (i.e. $548 \mathrm{~N}$, being $550 \mathrm{~N}$ the $\mathrm{EN} 520$ requirement).

- As regards the density, surface water absorption and surface hardness, all samples showed compliance with EN 520 specifications.

It should be noted that the different formulas and batches tested limit the outline of broader conclusions. Overall, this analysis provides the basis for future studies on RG quality criteria, the use of RG in additional plasterboard types as well as the examination of higher $\mathrm{RG}$ reincorporation rates.

\section{ACKNOWLEDGEMENT}

This study has been performed under the framework of the GtoG project, supported by the European Commission - DG Environment through the Life + programme; under contract number LIFE11 ENV/BE/001039. The article has been prepared during the research stay of Ana Jiménez at TU Delft, from February to April 2016, granted by the "XVI Convocatoria de ayudas del Consejo Social para el Fomento de la Internacionalización de Doctorados", Universidad Politécnica de Madrid.

\section{REFERENCES}

1. Jiménez-Rivero, A.; García-Navarro, J. (2016) Indicators to Measure the Management Performance of End-of-Life Gypsum: From Deconstruction to Production of Recycled Gypsum. Waste Biomass Valoriz. 7, 913-927. http://dx.doi. org/10.1007/s12649-016-9561-x.

2. Jiménez Rivero, A.; Sathre, R.; García Navarro, J. (2016) Life cycle energy and material flow implications of gypsum plasterboard recycling in the European Union. Resour. Conserv. Recycl. 108, 171-181. http://dx.doi.org/10.1016/j. resconrec.2016.01.014.

3. Jiménez Rivero, A.; De Guzmán Báez, A.; García Navarro, J. (2015) Gypsum Waste: Differences across Ten European Countries. Int. J. Sustain. Policy Pract. 11 [4], 1-9. 
4. The Council of the European Union. (2003) Council Decision of 19 December 2002 establishing criteria and procedures for the acceptance of waste at landfills pursuant to Article 16 of and Annex to Directive 1999/31/EC (2003/33/EC). Official Journal of the European Communities. L 11/27-11/49.

5. Plaza, C.; Xu Q.; Townsend, T.; Bitton, G.; Booth, M. (2007) Evaluation of alternative landfill cover soils for attenuating hydrogen sulfide from construction and demolition (C\&D) debris landfills. J. Environ. Manage. 84 [3], 314-322. http://dx.doi.org/10.1016/j.jenvman.2006.06.001.

6. Ding, G.K.C. (2008) Sustainable construction-The role of environmental assessment tools. J. Environ. Manage. 86 [3], 451-464. http://dx.doi.org/10.1016/j.jenvman.2006. 12.025 .

7. Suárez, S.; Roca, X.; Gasso, S. (2016) Product-specific life cycle assessment of recycled gypsum as a replacement for natural gypsum in ordinary Portland cement: application to the Spanish context. J. Clean. Prod. 117, 150-159. http:// dx.doi.org/10.1016/j.jclepro.2016.01.044.

8. Chandara, C.; Azizli, K.A.M.; Ahmad, Z.A.; Sakai, E. (2009) Use of waste gypsum to replace natural gypsum as set retarders in portland cement. Waste manage. 29 [5] 1675-9. http://dx.doi.org/10.1016/j.wasman.2008.11.014.

9. Kuttah, D.; Sato, K. (2015) Review on the effect of gypsum content on soil behavior. Transport. Geotechnics 4, 28-37. http://dx.doi.org/10.1016/j.trgeo.2015.06.003.

10. Jang, Y.-C.; Townsend, T. (2001) Sulfate leaching from recovered construction and demolition debris fines. $A d v$. Environ. Res. 5 [3], 203-217. http://dx.doi.org/10.1016/ S1093-0191(00)00056-3.

11. GtoG project. (2013) Life+ Gypsum to Gypsum (GtoG) project 'From production to recycling: a circular economy for the European Gypsum Industry with the Demolition and Recycling Industry' LIFE11 ENV/BE/001039, http:// gypsumtogypsum.org (retrieved 05.12.16.)

12. GtoG project. (2015) DC2: Protocol of action B2.2: Quality criteria for recycled gypsum, technical and toxicological parameters LIFE11 ENV/BE/001039, http:// gypsumtogypsum.org/documents/quality-criteria-forrecycled-gypsum-technical-and-toxicological-parameters. pdf (retrieved 05.12.16.).

13. CEN (2009) EN 520:2004+A1. Gypsum plasterboards Definitions, requirements and test methods.
14. VGB (2008) VGB-M 701e. Instruction Sheet Analysis of Analysis of FGD Gypsum FGD gypsum.

15. CEN (2012) EN 933-1:2012. Tests for geometrical properties of aggregates - Part 1: Determination of particle size distribution - Sieving method.

16. CEN (2002) EN 13137:2002. Characterization of waste - Determination of total organic carbon (TOC) in waste, sludges and sediments.

17. CEN (2007) ISO 11885:2007. Water quality - Determination of selected elements by inductively coupled plasma optical emission spectometry (ICP-OES).

18. GtoG project. (2015) DB4: Report of Production Process Parameters LIFE11 ENV/BE/001039, http://gypsumtogypsum.org/documents/report-on-production-process-parameters.pdf (retrieved 05.12.16.).

19. WRAP; Environment Agency (2013) Quality Protocol. Gypsum. End of waste criteria for the production and use of recycled gypsum from waste plasterboard.

20. Bundesverband der Gipsindustrie e.V. (2013) Recycled gypsum (RC-gypsum). Initial test for recycling plants, quality management, quality requirements and analysis methods.

21. Beckert, J. (1990) Comparison of natural gypsum and FGD gypsum: studies for a comparative assessment of the health impact of natural gypsum and FGD gypsum from coal-fired power plants with a view to their use in the manufacture of building. materials. VGB technical scientific reports "Thermal power plants", 707

22. GtoG project. (2013) DA1: Inventory of current practices LIFE11 ENV/BE/001039, http://gypsumtogypsum.org/ documents/deliverable-a1-report-on-current-practices.pdf (retrieved 05.12.16.).

23. Venta, G.J. (1997) Life cycle analysis of gypsum board and associated finishing products.

24. Roskill (2014) Gypsum and Anhydrite: Global Industry Markets and Outlook.

25. WRAP and Environmental Resources Management Ltd (ERM). (2008) Technical Report: Life Cycle Assessment of Plasterboard.

26. Henkels, P.J.; Gaynor, J.C. (1996) Characterizing synthetic gypsum for wallboard manufacture. ACS Division of Fuel Chemistry, Preprints 41 [2], 569-574.

27. WRAP; BSI (2013) PAS 109:2013. Specification for the production of reprocessed gypsum from waste plasterboard. 